\title{
Procjena primjene smjernica za prevenciju kardiovaskularnih bolesti u obiteljskoj medicini u Hrvatskoj
}

\section{Evaluating guideline applicaion for the prevention of cardiovascular diseases in Croatian family practice}

\author{
(DIno Kermc ${ }^{*}$, \\ Danko Relić ${ }^{2}$, \\ (D) Milan Milošević², \\ DZlata Ožvačić-Adžić ${ }^{2}$ \\ DRichard J. Schuster ${ }^{3}$, \\ DVenija Cerovečki ${ }^{2}$ \\ 'Dom zdravlja Zagreb - Centar, \\ Zagreb, Hrvatska \\ ${ }^{2}$ Medicinski fakultet \\ Sveučilišta u Zagrebu, \\ Zagreb, Hrvatska \\ ${ }^{3}$ School of Public Health \\ University of Haifa, Haifa, \\ Israel \\ 'Health centre Zagreb - Centar \\ Zagreb, Croatia \\ 2University of Zagreb, School \\ of Medicine, Zagreb, Croatia \\ ${ }^{3}$ School of Public Health, \\ University of Haifa, Haifa, \\ Izrael
}

RECEIVED:

October 25, 2018

ACCEPTED:

November 5, 2018

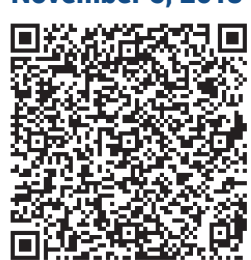

KLJUČNE RIJEČl: pridržavanje smjernica, kardiovaskularne bolesti, obiteljska medicina.

KEYWORDS: guideline adherence, cardiovascular diseases, family practice.

CITATION: Cardiol Croat. 2018;13(11-12):425. | https://doi.org/10.15836/ccar2018.425

*ADDRESS FOR CORRESPONDENCE: Ino Kermc, Dom zdravlja Zagreb - Centar, Runjaninova 4, HR-10000 Zagreb, Croatia. / Phone: +385-91-547-8844 / E-mail: ino.kermc@gmail.com

ORCID: Ino Kermc, https://orcid.org/0000-0002-3254-7022 • Danko Relić, https://orcid.org/0000-0001-6208-5888 Milan Milošević, https://orcid.org/0000-0001-9008-7645 • Zlata 0žvačić-Adžić, https://orcid.org/0000-0003-3524-6353 Richard J. Schuster, https://orcid.org/0000-0002-1825-5816 • Venija Cerovečki, https://orcid.org/0000-0003-2670-8712

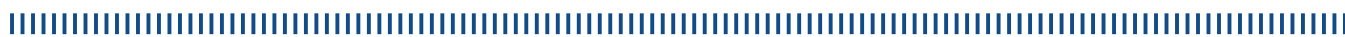

Uvod: Kardiovaskularne bolesti (KVB) predstavljaju vodeći uzrok smrti u razvijenim zemljama svijeta, ali i u Republici Hrvatskoj te prevencija KVB ostaje iznimno značajan čimbenik u smanjenju ukupne smrtnosti ${ }^{1}$. Europsko kardiološko društvo u suradnji sa srodnim stručnim društvima redovito izdaje i revidira s mjernice u svrhu prevencije KVB. Opći cilj ovog istraživanja je procijeniti primjenu smjernica za prevenciju KVB u radu obiteljskih liječnika. Specifični ciljevi su ispitati dostupnost smjernica obiteljskim liječnicima, korištenje smjernica u svakodnevnom radu te pridržavanje smjernica u skrbi za pacijente s rizikom za razvoj KVB.

Metode: Presječnim istraživanjem na prigodnom uzorku od 745 obiteljskih liječnika prikupljeni su podaci o obilježjima liječnika (dob, spol, status ordinacije) te dostupnosti, korištenju i pridržavanju smjernica za prevenciju KVB. Korišteni su statistički postupci deskriptivne statistike: opis i analiza distribucije uporabom apsolutnih brojeva i relativnih frekvencija.

Rezultati: Istraživanjem je obuhvaćeno 484 obiteljskih liječnika (stopa odgovora 65,0\%) od čega 422 (87,1\%) žena i 62 (12,5\%) muškarca. Većina ispitanika bila je u dobi do 55 godina ( $\mathrm{N}=346,71,5 \%)$ te imala status liječnika u koncesiji (N=339, 70,1\%). Obiteljski liječnici su dostupnost smjernica procijenili čestom i vrlo čestom u 60,7\% konzultacija u obiteljskoj medicini. Njih 64,7\% od ukupnog broja je procijenilo kako smjernice za prevenciju KVB koristi u više od $60 \%$ pacijenata, ali se svega njih 15,9\% striktno pridržava smjernica.

Zaključak: Razmjerno velikom broju liječnika obiteljske medicine su smjernice za prevenciju KVB nedostupne. Potrebno je pronaći načine kojima bi se olakšao pristup smjernicama i time potaknulo njihovo korištenje. Rezultati o procjeni pridržavanja smjernica pokazuju ono na što i autori smjernica upućuju, a to je da se smjernice trebaju implementirati u kliničku praksu sukladno liječnikovom znanju, iskustvu i pacijentovoj sklonosti te uvažavajući socijalno, kulturološko i ekonomsko okružje, poštujući u potpunosti model osobi usmjerene skrbi. 2,3
Introduction: Cardiovascular diseases (CVD) are the lead ing cause of death in developed countries of the world including Republic of Croatia. The prevention of CVD remains an important factor in reducing total mortality ${ }^{1}$ The European Society of Cardiology and related professional societies regularly publish and revise guidelines on CVD prevention. The general objective of this study is to evaluate the appliance of guidelines on CVD prevention in the family physicians' daily practice. Specific objectives are to examine the availability of guidelines for family physicians, the use of guidelines in their daily work and adherence to guidelines while treating patients with risk factors for CVD.

Methods: Research was conducted on a convenient sample of 745 family physicians. Data on physician's characteristics (age, sex, practice status) and availability, usage and adherence to CVD prevention guidelines were collected. Appropriate statistical procedures have been used: description and distribution analysis using absolute numbers and relative frequencies.

Results: The survey included 484 family physicians (response rate $65.0 \%$ ) of which 422 (87.1\%) women and 62 (12.5\%) men. The majority of the respondents were up to 55 years old ( $\mathrm{N}=346,71.5 \%)$, holding a private practice in concession (N=339, 70.1\%). Family physicians assessed the availability of guidelines as frequent and very frequent in $60.7 \%$ of consultations. Furthermore, $64.7 \%$ of the total number of respondents said they used CVD prevention guidelines in more than $60 \%$ of patients, but only $15.9 \%$ of respondents strictly adhered to the guidelines.

Conclusion: Relatively large number of family physicians has no CVD prevention guidelines available. It is necessary to find ways to facilitate access to the guidelines and thus encourage their use. Assessment of guideline adherence points out that the quidelines should be implemented in clinical practice in accordance with knowledge, experience, patient preferences, and the social, cultural and economic environment, respecting the model of personoriented care. ${ }^{2,3}$

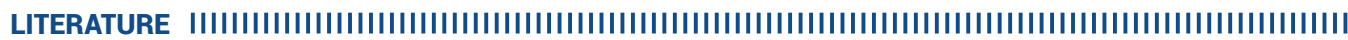

1. Kralj K, Brkić Biloš I, Corić T, Silobrčí Radić M, Šekerija M. Chronic Noncommunicable diseases - Burden of disease in the population of Croatia. Cardiol Croat. 2015;10(7-8):167-175. https://doi.org/10.15836/ccar.2015.167

2. Piepoli MF, Hoes AW, Brotons C, Hobbs RFD, Corra U; Task Force for the 2016 guidelines on cardiovascular disease prevention in clinical practice. Main messages for primary care from the 2016 European Guidelines on cardiovascular disease prevention in clinical practice. Eur J Gen Pract. 2018 Dec;24(1):51-56. https://doi:10.1080/13814788.2017.1398320

3. Freeman TR. McWhinney's textbook of family medicine. Oxford University Press; 2016. 